\title{
ANALISIS PENERAPAN COST REDUCTION DALAM PENINGKATAN LABA
}

(Studi pada PD Bank Perkreditan Rakyat di Jawa Barat)

\author{
Mohamad Iqbal Nikmatullah \\ (Program Studi Akuntansi FPEB Universitas Pendidikan Indonesia) \\ Agus Widarsono \\ (Program Studi Akuntansi FPEB Universitas Pendidikan Indonesia)
}

\begin{abstract}
This research purpose to know how application of Cost Reduction within increase profit PD. Bank Perkreditan Rakyat in West Java based on one of Cost Reductiontools is Fixed Cost Analysis. This research method used descriptive quantitative. The sampling technique using non-probability sampling with purposive sampling approach with criteria (1) PD BPR in West Java publishes financial report in Bank Indonesia for three years; (2) PD BPR good categorized according to the ratio of capital adequate ratio (CAR); (3) PD BPR has positive ratio return on asset (ROA); (4) PD BPR with total assets of more than the average total assets $P D B P R$ in West Java. The results showed that the average value of fixed cost ratio from year to year has decline, it's inversely with the value of earnings from year to year increase. It shows that the efficiency carried out use fixed cost aset affect to profitability. The proportion of lower fixed cost give opportunities for PD BPR to reach more income than expenditure variable, while result the breakeven analysis showed absence of effective implementation of cost reduction in the interest sector BPR was indicated by the absence of a link between the growth rate of the increase in profit spread.
\end{abstract}

Keywords : Cost Reduction, Breakeven Analysis, Fixed Cost Analysis, PD BPR Jawa Barat

\section{Pendahuluan}

Perbankan merupakan salah satu sektor ekonomi yang sangat penting peranannya dalam pembangunan ekonomi Indonesia, tidak hanya di Indonesia, di banyak negara industri, perbankan sangat dibutuhkan terutama dalam pembiayaan aktivitas yang berhubungan dengan uang (Permono, 2000 : 1). Bank adalah dana usaha yang menghimpun dana dari masyarakat dalam bentuk simpanan dan menyalurkannya kepada masyarakat dalam bentuk kredit dan atau bentuk-bentuk lainnya dalam rangka meningkatkan taraf hidup rakyat banyak (Hasibuan,2008 : 1). Bank Perkreditan Rakyat merupakan bagian dari sistem perbankan yang mempunyai andil yang cukup besar bagi perekonomian Indonesia. BPR merupakan salah satu jenis bank yang kegiatan usahanya terutama ditujukan untuk melayani usaha-usaha kecil dan masyarakat di daerah pedesaan. Kegiatan usaha yang diperkenankan dilakukan oleh BPR sangat terbatas dibandingkan dengan 
Bank Umum, yaitu hanya meliputi penghimpunan dana dari masyarakat dalam bentuk simpanan berupa deposito berjangka, tabungan, memberikan kredit, serta menempatkan dana dalam bentuk SBI, deposito berjangka, sertifikat deposito dan/atau tabungan pada bank lain. BPR tidak diperkenankan menerima simpanan berupa giro dan ikut serta dalam lalu lintas pembayaran serta melakukan kegiatan usaha selain yang diperkenankan. Selain itu, BPR tidak diperkenankan melakukan kegiatan usaha dalam valuta asing kecuali sebagai pedagang valuta asing (dengan izin Bank Indonesia), melakukan penyertaan modal, dan melakukan usaha asuransi. Adapun wilayah kantor operasionalnya dibatasi dalam 1 (satu) provinsi.

Berdasarkan badan hukumnya, BPR bisa dikategorikan menjadi tiga jenis badan hukum yaitu BPR yang berbadan hukum Perusahaan Daerah (PD), Perseroan Terbatas (PT), dan Koperasi (KOP). Menurut data statistik yang dikeluarkan oleh Bank Indonesia jumlah kelembagaan BPR selalu menurun dari tahun ke tahun dan terlihat jelas bahwa penurunan kuantitas kelembagaan BPR yang berbadan hukum Perusahaan Daerah lebih signifikan penurunannya, bahkan tidak pernah mengalami kenaikan.

Tabel 1

Jumlah BPR di Indonesia dan Jawa Barat

\begin{tabular}{ccccccccc}
\hline \multirow{2}{*}{ Tahun } & \multicolumn{4}{c}{ Jumlah BPR di Indonesia } & \multicolumn{3}{c}{ Jumlah BPR di Jawa Barat } \\
& PT & PD & KOP & Jumlah & PT & PD & KOP & Jumlah \\
\hline 2013 & 1380 & 228 & 33 & 1.641 & 239 & 64 & 2 & 304 \\
2012 & 1391 & 229 & 33 & 1.653 & 240 & 65 & 2 & 307 \\
2011 & 1388 & 247 & 34 & 1.669 & 240 & 83 & 2 & 325 \\
2010 & 1384 & 288 & 34 & 1.706 & 244 & 130 & 2 & 376 \\
2009 & 1357 & 324 & 34 & 1.733 & 243 & 153 & 2 & 398 \\
\hline
\end{tabular}

Sumber : www.bi.go.id (data diolah)

Jumlah BPR yang selalu menurun bisa menjadi sebuah pertanyaan. Menurut Budi Hermana dalam pena.gunadhrama.ac.id, penurunan bisa terjadi karena makin banyak BPR yang ditutup atau bangkrut. Penutupan atau kebangkrutan tersebut menjadi sinyal bahwa bisnis keuangan melalui BPR tidak menunjukkan kinerja atau prospek yang menjanjikan. Walau demikian, BPR sebagai suatu lembaga pembiayaan UMKM, dari tahun ke tahun terus menunjukkan perkembangan yang sangat baik. Perkembangan yang sangat baik itu dilihat dari berbagai ukuran misal dari dana yang dihimpun, kredit yang disalurkan, sampai kepada volume usaha. Trend yang meningkat tadi mengindikasikan bahwa BPR dibutuhkan masyarakat.Perjalanan BPR sebagai bank berskala kecil menghadapi berbagai masalah baik dari sisi kelembagaan maupun dari sisi operasionalnya, sehingga berakibat pada operasional BPR yang belum efisien. Hal tersebut diantaranya tercermin dari suku bunga BPR yang masih tinggi. Tingginya suku bunga tersebut merupakan salah satu indikasi bahwa BPR belum mampu mengefisienkan biaya operasionalnya. Paulus Yoga mengungkapkan dalam sebuah harian kabar online (infobanknews.com, 7 Desember 2011), Perbarindo tidak menampik tingkat suku bunga kredit BPR masih lebih tinggi dibanding Bank Umum, akibat tingginya biaya dana dan overhead. Oleh karena itu, diperlukan langkah-langkah untuk meningkatkan kinerja BPR.

Alokasi biaya harus memperhitungkan efektifitas dan efisiensi yang berarti alokasi biaya tertentu harus menciptakan pendapatan tertentu yang harus 
dialokasikan lebih tinggi dari alokasi biayanya. Salah satu metode yang saat ini sedang berkembang untuk mencapai efektivitas dan efisiensi biaya adalah dengan menerapkan Cost Reduction System. Cost Reduction adalah cara termudah dan paling pasti cara untuk meningkatkan keuntungan dalam jangka pendek. Hal ini juga dapat menjadi penggerak utama panjang - pertumbuhan jangka, jika ditangani dengan benar. Hal tersebut dikarenakan pengurangan biaya sepenuhnya dalam kendali perusahaan. Cukup menentukan area untuk pengurangan biaya dan menerapkannya. Cost Reduction adalah jalan paling sederhana untuk meningkatkan profitabilitas dan arus kas ditingkatkan (Steven M. Bragg, 2010 : 7).

Di Eropa, industri perbankan Eropa sudah bergeser mengarah ke arah Cost Reduction dan Cost Transformation. Dalam jurnalnya yang berjudul "Cost Transformation Imperative For European Banks", Roland Berger menemukan bahwa bank perlu menargetkan peningkatan biaya jangka pendek dan penyederhanaan jangka panjang untuk memulihkan profitabilitas. Bank akan mampu mengurangi biaya pokok mereka dengan setidaknya $10 \%$ selama lima tahun ke depan untuk mencapai rasio biaya terhadap pendapatan $55 \%$ di lima tahun kedepan, dengan asumsi lingkungan pertumbuhan pendapatan stabil. Ia memprediksi bahwa jika lingkungan perbankan memburuk, pengurangan biaya $17 \%$ dapat diminta. Setengah dari pengurangan target total akan dibuat dalam biaya SDM dan setengah lainnya dalam biaya eksternal (IT, real estate serta biaya lainnya). Saat ini banyak bank Eropa telah mengumumkan penerapan program Cost Reduction dalam usahanya. Namun, analisis Roland Berger mengungkapkan bahwa di antara 25 teratas, hanya sepertiga memiliki rencana transformasi biaya ambisius. Ia mengungkapkan ada perbedaan pendekatan transformasi biaya yang harus dilakukan di beberapa Negara.

Berdasarkan latar belakang peneliti ingin mengetahui bagaimana penerapan Cost Reduction dalam peningkatan laba PD. Bank Perkreditan Rakyat di Jawa Barat berdasarkan Cost Reduction tools yaitu Fixed Cost Analysis. Dan tujuan penelitian ini adalah untuk mengetahui bagaimana penerapan Cost Reduction dalam peningkatan laba PD. Bank Perkreditan Rakyat di Jawa Barat.

\section{Kajian Pustaka}

Dalam situasi bisnis perbankan yang kompetitif, penentuan besarnya biaya dana merupakan aktivitas penting. Biaya dalam aktivitas bisnis perbankan adalah pengorbanan yang dilakukan suatu bank dalam memperoleh sejumlah dana dari masyarakat guna menjalankan kegiatan operasionalnya. Biaya operasi merupakan salah satu elemen yang paling penting dalam aktivitas ekonomi pada suatu perusahaan dalam pembentukan laba. Menurut Nafarin (2004 : 67) menyatakan bahwa, biaya operasi adalah seluruh pengeluaran yang terjadi dalam suatu organisasi guna pelaksanaan aktivitas serta pencapaian tujuan yang telah ditentukan.Beban operasional ini adalah semua biaya yang berhubungan langsung dengan kegiatan usaha bank yang diperinci sebagai berikut (Siamat, $2005: 384$ ); (1) Beban bunga; (2) Beban penghapusan aktiva produktif; (3) Beban estimasi kerugian komitmen dan kontigensi; (4) Beban operasional lainnya yang terdiri dari : (a) Beban administrasi dan umum; (b) Beban personalia; (3) Beban penurunan nilai surat berharga; (3) Beban transaksi valas. 
Cost Reduction didefinisikan sebagai usaha me-manage aktivitas yang berhubungan dengan proses produksi dapat mengurangi biaya produksi dengan mengeliminasi biaya yang seharusnya tidak perlu terjadi.. Erly Sherlita mengungkapkan dalam jurnal ilmiahnya, Cost Reduction memfokuskan pengurangan biaya pada penyebab timbulnya pemborosan yaitu kualitas. Tujuan perusahaan melakukan Cost Reduction bukan hanya untuk mencapai standar yang ditetapkan tapi juga untuk mengurangi biaya secara bertahap di bawah standar agar terdapat efisiensi usaha, sehingga biaya yang dikeluarkan dapat diminimumkan dan laba yang diperoleh maksimal. Disamping itu kualitas produk tetap dipertahankan sehingga kualitasnya tidak menurun dan tidak mempengaruhi penjualan produk tersebut.

Penerapan Cost Reduction akan efektif jika diterapkan dalam posisi yang tepat yang dihasilkan dari proses analisa komperhensif terlebih dahulu. Analisa ini harus dilakukan dengan mencermati biaya secara menyeluruh. Agar penerapan Cost Reduction berjalan secara efektif, maka penerapannya harus dilakukan secara parsial dan dikhususkan pada area tertentu. Steven M. Bragg (2010 : 37) mengkategorikan area Cost Reduction dalam beberapa pos inti biaya yaitu; (1) production cost area; (2) selling and marketing cost area; dan; (3) payroll cost area.

BPR merupakan bagian dari sistem perbankan yang mempunyai andil yang cukup besar bagi perekonomian Indonesia. BPR sebagai satu jenis bank yang kegiatan usahanya terutama ditujukan untuk melayani usaha-usaha kecil dan masyarakat di daerah pedesaan. Kegiatan usaha yang diperkenankan dilakukan oleh BPR sangat terbatas dibandingkan dengan Bank Umum, yaitu hanya meliputi penghimpunan dana dari masyarakat dalam bentuk simpanan berupa deposito berjangka, tabungan dan/atau bentuk lainnya yang dipersamakan dengan itu, memberikan kredit serta menempatkan dana dalam bentuk SBI, deposito berjangka, sertifikat deposito dan/atau tabungan pada bank lain.

Menurut data statistik yang dikeluarkan oleh Bank Indonesia jumlah BPR selalu menurun dari tahun ke tahun. Penurunan jumlah BPR bisa menjadi sebuah pertanyaan atas apa yang menyebabkan hal tersebut. Dalam sebuah surat kabar online, finance.detik.com, Direktur Kredit BPR dan UMKM BI Ratna E. Amiaty mengatakan saat ini memang masih terdapat BPR yang masih tidak efisien dalam menjalankan bisnisnya. Ketidak efisienan tersebut mengindikasikan bahwa BPR belum mampu menegelola biaya operasionalnya secara efisien. Jika melihat dari badan hukum BPR, maka BPR yang berbadan hukum Perusahaan Daerah mengalami penurunan yang lebih signifkan. Tercatat dari Tahun 2009 sampai dengan Bulan September 2013, jumlah BPR yang berbadan hukum PD secara kelembagaan menurun drastis dari tahun ke tahun. Hal tersebut mengindikasikan kemampuan BPR yang berbadan hukum PD belum bisa mengelola pendapatan dan beban operasional secara efektif dan efisien. Karena efektifitas dan efisiensi pengelolaan beban akan berdampak positif terhadap kinerja keuangan.

Mengutip dari apa yang diungkapkan oleh Roland Berger dalam presentasinya yang berjudul Cost Transformation Imperative For European Banks (2012 : 2), untuk mencapai efektifitas dan efisiensi laba, perbankan di Amerika dan Eropa telah banyak berhasil menerapkan program cost reduction. Perbankan di Eropa dan Amerika telah berhasil memangkas biaya operasionalnya dan menghasilkan tingkat laba yang lebih baik. Namun program cost reduction 
tersebut masih belum banyak diterapkan di industri perbankan Indonesia. Dengan mereferensi keberhasilan perbankan di Eropa dan Amerika dalam menerapkan cost reduction, maka dengan BPR menerapkan hal yang sama, maka BPR akan dapat mencapai efisiensi dan efektifitas yang diharapkan sehingga mampu mempertahankan keberlangsungan bisnisnya. Efisiensi dan efektifitas tersebut dapat tercermin dari tingkat kesehatan bank dan perolehan Laba yang optimal. Berdasarkan uraian diatas maka peneliti merumuskan hipotesis bagaimana penerapan cost reduction berperan dalam peningkatan laba.

\section{Metode Penelitian}

Objek penelitian yang berkaitan dengan penelitian ini adalah penerapan Cost Reduction dan laba perbankan. Penelitian ini akan dilakukan pada PD Bank Perkreditan Rakyat yang berlokasi di Jawa Barat. Dengan menggunakan objek tersebut, peneliti ingin menganalisa bagaimana penerapan Cost Reduction dalam meningkatkan laba bank di PD Bank Perkreditan Rakyat di Jawa Barat. Penelitian ini dirancang dengan analisis deskriptif melalui pendekatan kuantitatif. Dalam penelitian ini terdapat satu variabel yaitu penerapan Cost Reduction. Cost Reduction tersebut dianalisis dengan menggunakan Cost Reduction tools yaitu Fixed Cost Analysis dan Breakeven Analysis.

Fixed Cost Analysis dilakukan dengan melihat nilai Fixed Cost Ratio dengan cara melihat proporsi fixed cost terhadap total cost dengan terlebih dahulu menganalisa dan mengkalisifikasikan akun-akun beban yang disajikan pada laporan keuangan publikasi BPR menggunakan cost behavior analysis. Cost behavior analysis yang digunakan yaitu dengan menggunakan profesional judgement. Metode ini digunakan karena profesional judgement merupakan metode menentukan perilaku biaya yang paling luas digunakan (Hansen and Mowen, 2009 : 121). Metode ini memiliki banyak bentuk, secara sederhana seorang profesional menentukan biaya aktivitas tertentu menjadi kategori tetap dan lainnya menjadi kategori variabel tanpa menghiraukan kategori biaya campuran. Selain itu, daya tarik metode ini terletak pada kesederhanaanya. Metode ini menggunakan pengalaman atau kajian teoritis dalam judgement yang dilakukan. Sedangkan breakeven analysis dilakukan dengan melihat nilai interest spread, yaitu selisih antara pendapatan bunga dikurangi dengan beban bunga yang kita berikan kepada pihak ketiga.

Populasi dalam penelitian ini adalah Laporan Keuangan Publikasi Bank Perkreditan Rakyat yang berbadan hukum Perusahaan Daerah yang ada di Jawa Barat berjumlah 64 BPR (sumber : www.bi.go.id).Teknik sampling yang digunakan dalam penelitian ini adalah non-probability sampling dengan pendekatan sampling purposive.Sampel dalam penelitian ini adalah laporan keuangan BPR yang memenuhi kriteria (1) PD BPR di Jawa Barat yang mempublikasikan laporan keuangannya di Bank Indonesia selama tiga tahun berturut-turut; (2) PD BPR yang dikategorikan sehat menurut rasio capital adequate ratio (CAR); (3) PD BPR yang memiliki rasio return on asset (ROA) positif; (4) PD BPR yang memiliki total aset lebih dari rata-rata total aset PD BPR di Jawa Barat. Sehingga jumlah sampel pada penelitian ini adalah 14 laporan keuangan publikasi PD BPR. Dalam penelitian ini penulis menggunakan data sekunder yang diambil dari dokumen-dokumen yang berhubungan dengan masalah yang dibahas dalam penelitian.Data yang digunakan dalam penelitian ini 
adalah laporan keuangan publikasi tahun 2010-2012 dari Bank Perkreditan Rakyat yang berbadan hukum Perusahaan Daerah yang ada di Jawa Barat. Sumber data diambil dari website resmi Bank Indonesia.

\section{Hasil dan Pembahasan}

Fixed Cost Analysis yang digunakan mensyaratkan cost behavior analysis untuk mengklasifikasi akun-akun beban yang ada pada laporan keuangan publikasi PD BPR yang dipublikasikan oleh bank indonesia ke dalam dua akun besar yaitu beban tetap dan beban variabel. Cost behavior analysis yang digunakan yaitu dengan menggunakan profesional judgement. Metode ini digunakan karena profesional judgement merupakan metode menentukan perilaku biaya yang paling luas digunakan (Hansen and Mowen, 2009 : 121). Metode ini memiliki banyak bentuk, secara sederhana seorang profesional menentukan biaya aktivitas tertentu menjadi kategori tetap dan lainnya menjadi kategori variabel tanpa menghiraukan kategori biaya campuran. Selain itu, daya tarik metode ini terletak pada kesederhanaanya. Metode ini menggunakan pengalaman atau kajian teoritis dalam judgement yang dilakukan. Hasil analisis cost behavior mengklasifikasikan macam-macam beban yang dalam laporan keuangan yang disajikan ke dalam 2 jenis beban, beban variabel dan beban tetap. Beban-beban yang termasuk ke dalam beban variabel adalah beban bunga dan beban non operasional. Sedangkan yang termasuk ke dalam beban tetap adalah beban personalia, beban administrasi dan umum, beban penyisihan aktiva produktif, dan beban operasional lainnya. Setelah dilakukan cost behavior analysis maka Fixed Cost Analysis dapat dilakuakn dengan melihat proporsi fixed cost terhadap total beban. Berikut nilai fixed cost hasil data yang telah diolah.

Tabel 2

Fixed Cost Ratio (2010 - 2012)

Dalam ribuan rupiah

\begin{tabular}{cccccc}
\hline \multirow{2}{*}{ No } & \multicolumn{2}{c}{ Nama BPR } & \multirow{2}{*}{ Kota } & \multicolumn{3}{c}{ Cost Ratio } \\
\cline { 4 - 5 } 1 & PD BPR Kota Bandung & Kota Bandung & $75,48 \%$ & $\begin{array}{c}71,69 \% \\
\text { Fixed }\end{array}$ & $65,28 \%$ \\
& KD BPR LPK & Kab. Cianjur & $75,44 \%$ & $76,95 \%$ & $74,33 \%$
\end{tabular}




\begin{tabular}{|c|c|c|c|c|c|}
\hline 3 & PD BPR Kab Bandung & Kab. Bandung & $77,47 \%$ & $73,67 \%$ & $76,18 \%$ \\
\hline 4 & PD BPR Sumedang & Kab. Sumedang & $69,66 \%$ & $74,89 \%$ & $71,04 \%$ \\
\hline 5 & PD BPR LPK Cipatujah & Kab. Tasikmalaya & $51,98 \%$ & $55,28 \%$ & $61,51 \%$ \\
\hline 6 & PD BPR LPK Garut Kota & Kab. Garut & $66,13 \%$ & $74,42 \%$ & $65,95 \%$ \\
\hline 7 & $\begin{array}{l}\text { PD BPR BKPD } \\
\text { Kuningan }\end{array}$ & Kab. Kuningan & $73,71 \%$ & $73,09 \%$ & $72,62 \%$ \\
\hline 8 & PD BPR Sukahaji & Kab. Majalengka & $70,50 \%$ & $71,95 \%$ & $71,34 \%$ \\
\hline 9 & $\begin{array}{l}\text { PD BPR LPK Jalan } \\
\text { Cagak }\end{array}$ & Kab. Subang & $57,44 \%$ & $60,90 \%$ & $57,96 \%$ \\
\hline 10 & PD BPR Subang & Kab. Subang & $63,54 \%$ & $65,93 \%$ & $63,94 \%$ \\
\hline 11 & PD BPR BP Kota Bogor & Kota Bogor & $76,25 \%$ & $72,46 \%$ & $69,64 \%$ \\
\hline 12 & PD BPR Kota Sukabumi & Kota Sukabumi & $56,29 \%$ & $56,34 \%$ & $70,32 \%$ \\
\hline 13 & PD BPR Artha Sukapura & Kota Tasikmalaya & $71,33 \%$ & $69,84 \%$ & $73,35 \%$ \\
\hline 14 & PD BPR Babakan & Kab. Cirebon & $53,99 \%$ & $56,67 \%$ & $62,22 \%$ \\
\hline \multicolumn{3}{|c|}{ Rata-rata } & $67,09 \%$ & $68,15 \%$ & $68,26 \%$ \\
\hline
\end{tabular}

Dari data tersebut terlihat bahwa secara rata-rata Fixed Cost Ratio dari tahun ke tahun mengalami penurunan walalupun tidak signifikan. Hal tersebut berbanding terbalik dengan nilai laba yang dari tahun ke tahun secara rata-rata selalu mengalami kenaikan. Nilai perolehan laba dari Tahun 2010 sampai dengan Tahun 2012 dapat dilihat pada tabel berikut

Tabel 3

Laba $(2010$ - 2012)

Dalam ribuan rupiah

\begin{tabular}{llcccr}
\hline \multirow{2}{*}{ No } & \multicolumn{1}{c}{ Nama BPR } & \multirow{2}{*}{ Kota } & \multicolumn{3}{c}{ Laba } \\
\cline { 5 - 6 } 1 & PD BPR Kota Bandung & Kota Bandung & 1.026 .489 & 60.393 & 4.733 \\
& PD BPR LPK & Kab. Cianjur & 1.791 .543 & 1.299 .576 & 1.052 .342 \\
2 & Warungkondang & Kab. Bandung & 2.596 .851 & 4.750 .443 & 2.946 .633
\end{tabular}




\begin{tabular}{|c|c|c|c|c|c|}
\hline 4 & PD BPR Sumedang & $\begin{array}{c}\text { Kab. } \\
\text { Sumedang }\end{array}$ & 957.181 & 5.296 & 1.945 .229 \\
\hline 5 & PD BPR LPK Cipatujah & $\begin{array}{c}\text { Kab. } \\
\text { Tasikmalaya }\end{array}$ & 4.381 .040 & 3.822 .246 & 3.133 .380 \\
\hline 6 & PD BPR LPK Garut Kota & Kab. Garut & 2.213 .864 & 858.656 & 311.874 \\
\hline 7 & PD BPR BKPD Kuningan & $\begin{array}{c}\text { Kab. } \\
\text { Kuningan }\end{array}$ & 512.451 & 475.115 & 1.331 .525 \\
\hline 8 & PD BPR Sukahaji & $\begin{array}{c}\text { Kab. } \\
\text { Majalengka }\end{array}$ & 923.199 & 1.752 .635 & 713.914 \\
\hline 9 & PD BPR LPK Jalan Cagak & Kab. Subang & 1.767 .579 & $(600.684)$ & 550.060 \\
\hline 10 & PD BPR Subang & Kab. Subang & 6.411 .752 & 6.083 .824 & 6.230 .734 \\
\hline 11 & PD BPR BP Kota Bogor & Kota Bogor & 3.034 .927 & 2.808 .258 & 2.635 .877 \\
\hline 12 & PD BPR Kota Sukabumi & $\begin{array}{c}\text { Kota } \\
\text { Sukabumi }\end{array}$ & 1.948 .110 & 1.671 .328 & 1.606 .855 \\
\hline 13 & PD BPR Artha Sukapura & $\begin{array}{c}\text { Kota } \\
\text { Tasikmalaya }\end{array}$ & 2.836 .408 & 2.387 .838 & 93.552 \\
\hline 14 & PD BPR Babakan & Kab. Cirebon & 2.122 .356 & 1.395 .910 & 1.201 .723 \\
\hline & Rata-rata & & 2.323 .125 & 1.912 .202 & 1.697 .031 \\
\hline
\end{tabular}

Berbanding terbalik dengan penurunan nilai Fixed Cost Ratio, nilai perolehan laba dari Tahun ke Tahun mengalami kenaikan. Hal tersebut menunjukkan bahwa efisiensi yang dilakukan dalam penggunaan fixed cost berpengaruh pada perolehan laba. Proporsi fixed cost yang lebih rendah memberikan peluang bagi PD BPR untuk meraih pendapatan yang lebih besar dari pengeluaran variabelnya.Perbandingan antara Fixed Cost Ratio dengan perolehan laba digambarkan dalam grafik berikut

\section{Perbandingan fixed cost ratio terhadap laba}

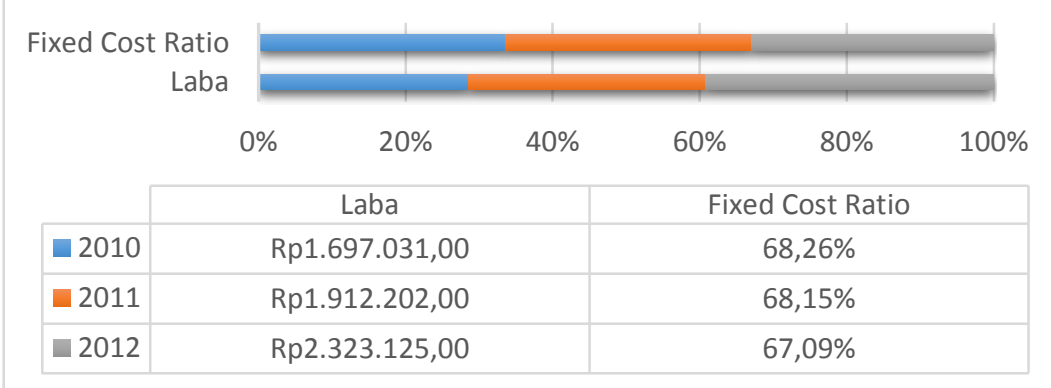

Breakeven analysis dilakukan dengan melihat nilai interest spread, yaitu selisih antara pendapatan bunga dikurangi dengan beban bunga yang kita berikan kepada pihak ketiga.Net interest spread dinilai dengan melihat bagaimana selisih 359 | Jurnal Riset Akuntansi dan Keuangan Vol.2 | No.2 | 2014 
pendapatan bunga dan beban bunga di Bank. Selisih tersebut akan menunjukkan kinerja operasional bank. Jika pendapatan bunga lebih besar dari beban bunga maka akan menghasilkan nilai spread positif, dan sebaliknya jika pendapatan bunga lebih kecil dari beban bunga maka akan menghasilkan nilai spread negatif. Berikut nilainet interest spread hasil data yang telah diolah

\section{Tabel 4}

Net interest spread $(2010$ - 2012)

Dalam ribuan rupiah

\begin{tabular}{|c|c|c|c|c|c|}
\hline \multirow{2}{*}{ No } & \multirow{2}{*}{ Nama BPR } & \multirow{2}{*}{ Kota } & \multicolumn{3}{|c|}{ Net interestSpread } \\
\hline & & & 2012 & 2011 & 2010 \\
\hline 1 & $\begin{array}{l}\text { PD BPR Kota } \\
\text { Bandung }\end{array}$ & Kota Bandung & 6.072 .453 & 5.370 .597 & 5.047 .989 \\
\hline 2 & $\begin{array}{l}\text { PD BPR LPK } \\
\text { Warungkondang }\end{array}$ & Kab. Cianjur & 10.714 .292 & 11.040 .541 & 3.240 .785 \\
\hline 3 & $\begin{array}{l}\text { PD BPR Kab } \\
\text { Bandung }\end{array}$ & Kab. Bandung & 24.513 .023 & 20.355 .921 & 17.372 .745 \\
\hline 4 & PD BPR Sumedang & $\begin{array}{c}\text { Kab. } \\
\text { Sumedang }\end{array}$ & 12.823 .928 & 12.985 .115 & 11.432 .490 \\
\hline 5 & $\begin{array}{l}\text { PD BPR LPK } \\
\text { Cipatujah }\end{array}$ & $\begin{array}{c}\text { Kab. } \\
\text { Tasikmalaya }\end{array}$ & 11.536 .173 & 8.819 .540 & 7.752 .033 \\
\hline 6 & $\begin{array}{l}\text { PD BPR LPK Garut } \\
\text { Kota }\end{array}$ & Kab. Garut & 10.514 .903 & 9.569 .899 & 2.286 .758 \\
\hline 7 & $\begin{array}{l}\text { PD BPR BKPD } \\
\text { Kuningan }\end{array}$ & Kab. Kuningan & 8.910 .197 & 7.926 .510 & 7.774 .801 \\
\hline 8 & PD BPR Sukahaji & $\begin{array}{c}\text { Kab. } \\
\text { Majalengka }\end{array}$ & 11.528 .630 & 11.200 .193 & 10.838 .807 \\
\hline 9 & $\begin{array}{l}\text { PD BPR LPK Jalan } \\
\text { Cagak }\end{array}$ & Kab. Subang & 12.490 .822 & 12.084 .616 & 2.545 .917 \\
\hline 10 & PD BPR Subang & Kab. Subang & 41.483 .506 & 35.259 .782 & 31.585 .305 \\
\hline 11 & $\begin{array}{l}\text { PD BPR BP Kota } \\
\text { Bogor }\end{array}$ & Kota Bogor & 6.542 .803 & 5.947 .216 & 5.475 .806 \\
\hline 12 & $\begin{array}{l}\text { PD BPR Kota } \\
\text { Sukabumi }\end{array}$ & $\begin{array}{c}\text { Kota } \\
\text { Sukabumi }\end{array}$ & 4.026 .108 & 3.549 .495 & 3.302 .172 \\
\hline 13 & $\begin{array}{l}\text { PD BPR Artha } \\
\text { Sukapura }\end{array}$ & $\begin{array}{c}\text { Kota } \\
\text { Tasikmalaya }\end{array}$ & 18.199 .718 & 16.178 .382 & 592.870 \\
\hline 14 & PD BPR Babakan & Kab. Cirebon & 5.350 .757 & 4.495 .273 & 4.236.535 \\
\hline & Rata-rata & & 13.193 .380 & 11.770 .220 & 8.106 .072 \\
\hline
\end{tabular}

Selanjutnya analisis breakeven dapat dihasilkan melalui perbandingan antara nilai $\Delta$ spread dengan laba di tahun berikutnya. $\Delta$ spread didapat dengan melihat perkembangan nilai spread dari tahun ke tahun. Jika nilai spread dari tahun ke tahun meningkat maka akan mengahsilkan nilai $\Delta$ spread positif, sedangkan jika nilai spread mengalami penurunan maka akan menghasilkan nilai $\Delta$ spread negatif. Berikut nilai $\Delta$ spread yang telah peneliti olah:

Tabel 5 
$\Delta$ spread $(2010$ - 2012)

Dalam ribuan rupiah

\begin{tabular}{|c|c|c|c|c|}
\hline \multirow{2}{*}{ No } & \multirow{2}{*}{ Nama BPR } & \multirow{2}{*}{ Kota } & \multicolumn{2}{|c|}{$\Delta$ spread } \\
\hline & & & 2012 & 2011 \\
\hline 1 & PD BPR Kota Bandung & $\begin{array}{c}\text { Kota } \\
\text { Bandung }\end{array}$ & 701.856 & 322.608 \\
\hline 2 & $\begin{array}{l}\text { PD BPR LPK } \\
\text { Warungkondang }\end{array}$ & Kab. Cianjur & $(326.249)$ & 7.799 .756 \\
\hline 3 & PD BPR Kab Bandung & $\begin{array}{c}\text { Kab. } \\
\text { Bandung }\end{array}$ & 4.157 .102 & 2.983 .176 \\
\hline 4 & PD BPR Sumedang & $\begin{array}{c}\text { Kab. } \\
\text { Sumedang }\end{array}$ & $(161.187)$ & 1.552 .625 \\
\hline 5 & PD BPR LPK Cipatujah & $\begin{array}{c}\text { Kab. } \\
\text { Tasikmalaya }\end{array}$ & 2.716 .633 & 1.067 .507 \\
\hline 6 & $\begin{array}{l}\text { PD BPR LPK Garut } \\
\text { Kota }\end{array}$ & Kab. Garut & 945.004 & 7.283.141 \\
\hline 7 & $\begin{array}{l}\text { PD BPR BKPD } \\
\text { Kuningan }\end{array}$ & $\begin{array}{c}\text { Kab. } \\
\text { Kuningan }\end{array}$ & 983.687 & 151.709 \\
\hline 8 & PD BPR Sukahaji & $\begin{array}{c}\text { Kab. } \\
\text { Majalengka }\end{array}$ & 328.437 & 361.386 \\
\hline 9 & $\begin{array}{l}\text { PD BPR LPK Jalan } \\
\text { Cagak }\end{array}$ & Kab. Subang & 406.206 & 9.538 .699 \\
\hline 10 & PD BPR Subang & Kab. Subang & 6.223 .724 & 3.674 .477 \\
\hline 11 & PD BPR BP Kota Bogor & Kota Bogor & 595.587 & 471.410 \\
\hline 12 & PD BPR Kota Sukabumi & $\begin{array}{c}\text { Kota } \\
\text { Sukabumi }\end{array}$ & 476.613 & $(440.016)$ \\
\hline 13 & PD BPR Artha Sukapura & $\begin{array}{c}\text { Kota } \\
\text { Tasikmalaya }\end{array}$ & 2.021 .336 & 15.585 .512 \\
\hline 14 & PD BPR Babakan & Kab. Cirebon & 855.484 & 258.738 \\
\hline & Rata-rata & & 1.423 .160 & 3.615 .052 \\
\hline
\end{tabular}

Spread yang tinggi memiliki potensi perolehan laba yang lebih baik, namun besarnya peningkatan laba tidak sebesar atau lebih besar dari peningkatan nilai spread. Untuk melihat berapa besar pengaruh perubahan nilai spread terhadap perolehan laba, maka dibandingkan nilai perubahan spread dengan nilai perubahan laba. Namun ternyata perubahan spread tidak selalu berbanding lurus dengan perubahan laba. Perubahan spread yang bernilai positif tidak selalu memberikan dampak peningkatan laba. Hasil tersebut menunjukan tidak adanya penerapan cost reduction yang efektif di sektor bunga BPR. Data menunjukkan pertumbuhan spread tidak selalu menghasilkan pertumbuhan laba. Hal tersebut berarti bahwa spread bukan merupakan hal yang utama yang mempengaruhi perolehan laba. Pendapatan selain pendapatan bunga harus dioptimalkan atau beban selain beban bunga harus diefisienkan sehingga laba dapat diperoleh secara 
maksimal. Namun disamping itu, penurunan nilai spread yang ditunjukkan dengan nilai $\Delta$ spreadyang negatif tidak berarti bahwa BPR menunjukkan kinerja yang buruk. Penurunan nilai spread bisa diakibatkan dengan proteksi BPR yang lebih terhapad resiko. Data menunjukkan bahwa kredit macet BPR setiap tahunnya mengalami peningkatan, dan hal tersebut memunculkan resiko yang besar. Resiko atas kredit macet tersebut dapat diantisipasi dengan pemberian pinjaman yang lebih sedikit kepada debitor, hal tersebut dapat menyebabkan perolehan pendapatan bunga menajdi lebih kecil sehingga terlihat bahawa nilai spread menurun dari Tahun sebelumnya. Selain itu, data statistik Komposisi Dana Pihak Ketiga BPR yang dirilis oleh Bank Indonesia menunjukkan bahwa dana yang dihimpun dari pihak ketiga BPR menunjukkan peningkatan di tiap Tahunnya, hal tersebut memaksa BPR untuk mengeluarkan beban bunga yang lebih besar sehingga menyebabkan nilai spread terlihat menurun dari Tahun sebelumnya.

\section{Simpulan}

Seiring dengan penurunan nilai Fixed Cost Ratio, nilai perolehan laba dari Tahun ke Tahun mengalami kenaikan. Hal tersebut menunjukkan bahwa efisiensi yang dilakukan dalam penggunaan fixed cost berpengaruh pada perolehan laba. Proporsi fixed cost yang lebih rendah memberikan peluang bagi PD BPR untuk meraih pendapatan yang lebih besar dari pengeluaran variabelnya. Sedangkan hasil breakeven analysis menunjukan tidak adanya penerapan cost reduction yang efektif di sektor bunga BPR itu ditunjukkan dengan tidak adanya keterkaitan antara pertumbuhan nilai spread terhadap peningkatan laba. Cost Reduction dapat dilakukan dengan efisiensi penggunaan beban tetap yang diantaranya adalah beban personalia, beban administrasi dan umum, beban penyisihan aktiva produktif, dan beban operasional lainnya. Cost Reduction pada beban tetap sesuai dengan Cost Reduction area yang dikemukakan oleh Steve M. Bragg (2010) yaitu payroll Cost Reduction area dan selling and marketing Cost Reduction area. Dalam payroll Cost Reduction area dapat dilakukan dengan Meminimalisisr pengeluaran payroll tanpa mengurangi kualitas outputdengan cara mengatur pola kerja dan mengefektifkan jam kerja sehingga tidak banyak pengeluaran untuk biaya lembur karyawan dan berdampak pada beban personalia PD BPR menjadi lebih rendah. Selain itu dalam selling and marketing Cost Reduction area dapat dilakukan dengan lebih mengefisiensikan beban-beban marketing bank diantaranya dengan management advertising yang lebih baik selain itu dengan melakukan customer class analysis, sales region analysis, dan sales efectiveness analysis secara optimal.

\section{Saran}

1. Dalam upaya mempertahankan, meningkatkan, dan memaksimalkan perolehan laba, PD BPR sebaiknya terus mengembangkan Cost Reduction system yang telah dilakukan dengan mengefisiensikan pengeluaran terutama difokuskan pada pos-pos dalam Cost Reduction areas yaitu production Cost Reduction area, payroll Cost Reduction area, dan selling and marketing Cost Reduction area.

2. Analisis cost behavior yang dilakukan yaitu menggunakan professional judgement pada penelitian ini lebih mereferensikan pada kajian teoritis 
karena keterbatasan akses peneliti untuk masuk ke bagian akunting di PD BPR guna mendapatkan profesioanl judgement yang bereferesni pengalaman yaitu akuntan di PD BPR

3. Penelitian ini dirancang dengan analisis deskriptif melalui pendekatan kuantitatif dengan menggunakan teknik Fixed Cost Analysisdan Breakeven Analysis dalam teknik analisis data. Untuk peneliti selanjutnya, sebaiknya dirancang dengan pendekatan kualitatif agar pengamatan dan analisa bisa dilakukan lebih mendalam dengan banyaknya Cost Reduction tools yang dpat digunakan untuk analisa kualitatif.

\section{Daftar Pustaka}

Bragg, Steven M. 2010. Cost Reduction Analysis. New Jersey : John Wiley and Sons.

Hansen dan Mowen. 2006. Buku I Management Accounting Edisi 7. Jakarta : Salemba Empat

Infobanknews. (2011, Desember). Bunga Kredit Tinggi, BPR Masih Mentok di Biaya Dana dan Overhead. Dalam www.infobanknews.com [online]. Tersedia www.infobanknews.com/2011/12/bunga-kredit-tinggi-bpr-masihmentok-di-biaya-dana-dan-overhead/ [13 Januari 2014]

Pedoman Akuntansi Bank Perkreditan Rakyat

Permono, Iswardono S dan Darmawan, 2000. Analisis Efisiensi Industri Perbankan Di Indonesia (Studi Kasus Bank-Bank Devisa di Indonesia Tahun 1991-1996). Jurnal Ekonomi dan Bisnis Indonesia. Vol. 15. Hal. 113.

Roland Berger. 2010. Cost Transformation Imperative For European Banks. Dalam www.rolandberger.com [online]. Tersedia http://www.rolandberger.com/expertise/industries/financial_services/201207-23-rbsc-pub-Cost_reduction_in_European_banking_sector.html. [8 Januari 2014]

Roland Berger. 2012. Cost Reduction in European Banking Sector [presentation]. Paris.

S.P. Hasibuan, Malayu. 2008. Dasar-dasar Perbankan. cetakan pertama. Jakarta : Bumi Aksara.

Undang-undang Nomor 10 tahun 1998

Undang-undang Nomor 14 Tahun 1967

Undang-undang Nomor 7 tahun 1992 tentang Perbankan 